\title{
Towards active lower limb prosthetic systems: design issues and solutions
}

\author{
Oliver Christ ${ }^{*}$ and Philipp Beckerle ${ }^{2}$ \\ From Robotics: Science and Systems 2013 Berlin, Germany. 28-Jun-16
}

\author{
${ }^{*}$ Correspondence: \\ oliver.christ@fhnw.ch \\ ${ }^{1}$ School of Applied \\ Psychology, Institute \\ Humans in Complex \\ Systems, University \\ of Applied Sciences and Arts \\ Northwestern Switzerland, \\ Olten, Switzerland \\ Full list of author information \\ is available at the end of the \\ article
}

Keywords: Prosthetics, Lower limb amputation, Engineering design, Biomechanics, Psychological adjustment

\section{Background}

A prosthesis is a crucial technical substitute that should restore biomechanical function and body integrity for people with lower limb loss or congenital limb absence [1]. Within the last decades, lower limb prostheses developed from passive mechanisms to adaptive mechatronic systems [2]. Contemporary, such prostheses evolve to robotic systems providing powered locomotion support by drives as shown in [3,4]. According to the review in from [5], 21 different active lower limb prostheses are found in the research literature. With such technologies, various new research questions arise and the idea of prosthesis technology simulation is being discussed [6, 7].

Technically, the mechatronic design of actuators and kinematics as well as the development of suitable control algorithms are challenging tasks [3, 4]. A promising approach to actuation is found in compliant actuators and kinematics that store and transfer energy between gait phases [8]. To command those actuators, controllers that mimic biological function during different gait situations, speeds, and transitions as the one propose by Grimmer et al. [9] are required.

Analyzing human biomechanics with and without considering the prosthetic system is a crucial basis for design and control that provides requirements and constrains [10]. Further, biomechanical studies can be used to assess the utility of active prostheses and indicate that those improve amputee gait $[3,11]$.

As prostheses are not only used by people, but aim at replacing lost parts of amputees' bodies, human factors show significant impact on prosthetic development from a psychological perspective [12-14]. Those comprise aspects such as acceptance [15] and integration to the body schema [16-20].

Those human factors impact technical design [21, 22] and need psychological methods to be surveyed [23-25] and considered in design [26]. Additionally, insights regarding human factors can be used to develop and improve novel techniques for movement rehabilitation, e.g., gait training in virtual reality environments [27-29].

(c) The Author(s) 2016. This article is distributed under the terms of the Creative Commons Attribution 4.0 International License (http://creativecommons.org/licenses/by/4.0/), which permits unrestricted use, distribution, and reproduction in any medium, provided you give appropriate credit to the original author(s) and the source, provide a link to the Creative Commons license, and indicate if changes were made. The Creative Commons Public Domain Dedication waiver (http://creativecommons.org/publicdomain/zero/1.0/) applies to the data made available in this article, unless otherwise stated. 
The articles in this supplement contribute to those topics by tackling elastic actuation, gait recognition and control, biomechanical analysis and simulation, human factors, and virtual reality rehabilitation.

\section{Authors' contributions}

Oliver Christ and Philipp Beckerle were both responsible for carrying out the literature search and writing the article. Both authors read and approved the final manuscript.

\section{Author details}

1 School of Applied Psychology, Institute Humans in Complex Systems, University of Applied Sciences and Arts Northwestern Switzerland, Olten, Switzerland. ${ }^{2}$ Institute for Mechatronic Systems in Mechanical Engineering, Technische Universität Darmstadt, Darmstadt, Germany.

\section{Competing interests}

The authors declare that they have no competing interests.

\section{Declarations}

This article has been published as part of BioMedical Engineering OnLine Vol 15 Suppl 3, 2016: Towards Active Lower Limb Prosthetic Systems: Design Issues and Solutions. The full contents of the supplement are available online at http:// biomedical-engineering-online.biomedcentral.com/articles/supplements/volume-15-supplement-3.

Published: 19 December 2016

\section{References}

1. Wetz HH. Einfluss des C-Leg-Kniegelenk-Passteiles der Fa. Otto Bock auf die Versorgungsqualität Oberschenkelamputierter. Der Orthopäde. 2005;4:298-319.

2. Berry D. Microprocessor prosthetic knees. Phys Med. 2006;17:91-113.

3. Au SK, Weber J, Herr H. Powered ankle-foot prosthesis improves walking metabolic economy. IEEE Trans Robot. 2009;25:51-66.

4. Holgate MA, Hitt JK, Bellman RD, Sugar TG, Hollander KW. The SPARKy (Spring Ankle with Regenerative kinetics) project: choosing a DC motor based actuation method. In: 2008 2nd IEEE RAS \& EMBS international conference on biomedical robotics and biomechatronics. IEEE; 2008. p. 163-8.

5. Windrich M, Grimmer M, Christ O, Rinderknecht S, Beckerle P. Active lower limb prosthetics: a systematic review of design issues and solutions. 2016.

6. Wojtusch J, Beckerle P, Christ O, Wolff K, Von Stryk O, Rinderknecht S, Vogt J. Prosthesis-user-in-the-loop: a userspecific biomechanical modeling and simulation environment. In: 2012 annual international conference of the IEEE engineering in medicine and biology society. IEEE; 2012. p. 4181-4.

7. Beckerle P, Lahnstein L, Wojtusch J, Rinderknecht S, von Stryk O. Conception and design of a hardware simulator for restoring lost biomechanical function. In: 2013 IEEE international conference on systems, man, and cybernetics. IEEE; 2013. p. 1906-11.

8. Cherelle P, Grosu V, Cestari M, Vanderborght B, Lefeber D. The AMP-foot 3-new generation propulsive prosthetic feet with explosive motion characteristics_design and experiments. 2016

9. Grimmer M, Holgate M, Holgate R, Boehler A, Ward J, Hollander K, Sugar T, Seyfarth A. A powered prosthetic ankle joint for walking and running. 2016.

10. Perry J, Burnfield JM, Newsam CJ. Energy expenditure and gait characteristics of a bilateral amputee walking with c-leg prostheses compared with stubby and conventional articulating prostheses. Arch Phys Med Rehabil. 2004:85:1711-7.

11. Creylman V, Knippels I, Janssen P, Biesbrouck E, Lechler K, Peeraer L. Assessment of transfemoral amputees using a passive microprocessor-controlled knee versus an active powered microprocessor-controlled knee for level walking 2016.

12. Murray CD. The social meanings of prosthesis use. J Health Psychol. 2005;10(3):425-41.

13. Singh $\mathrm{R}$, Hunter J, Philip A. The rapid resolution of depression and anxiety symptoms after lower limb amputation. Clin Rehabil. 2007;21(8):754-9.

14. Holzer LA, Sevelda F, Fraberger G, Bluder O, Kickinger W, Holzer G. Body image and self-esteem in lower-limb amputees. PLoS ONE. 2014;9(3):e92943.

15. Christ O, Jokisch M, Preller J, Beckerle P, Wojtusch J, Rinderknecht S, Vogt J. User-centered prosthetic development: comprehension of amputees' needs. Biomed Eng. 2012;57(Suppl 1):1098-101.

16. Ehrsson HH, Rosén B, Stockselius A, Ragnö C, Köhler P, Lundborg G. Upper limb amputees can be induced to experience a rubber hand as their own. Brain. 2008;131(Pt 12):3443-52.

17. Marasco PD, Kim K, Colgate JE, Peshkin MA, Kuiken TA. Robotic touch shifts perception of embodiment to a prosthesis in targeted reinnervation amputees. Brain. 2011;134(Pt 3):747-58.

18. Schmalzl L, Thomke E, Ragnö C, Nilseryd M, Stockselius A, Ehrsson HH. "Pulling telescoped phantoms out of the stump": manipulating the perceived position of phantom limbs using a full-body illusion. Front Hum Neurosci. 2011;5:121.

19. Schmalzl L, Kalckerta A, Ragnöb C, Ehrsson HH. Neural correlates of the rubber hand illusion in amputees: a report of two cases. Neurocase. 2013;20(4):407-20. 
20. Christ O, Reiner M. Perspectives and possible applications of the rubber hand and virtual hand illusion in non-invasive rehabilitation: technological improvements and their consequences. Neurosci Biobehav Rev. 2014;44(7):33-44.

21. Jacques GE, Ryan S, Naumann S, Milner M, Cleghorn WL. Application of quality function deployment in rehabilitation engineering. IEEE Trans Rehabil Eng. 1994;2(3):158-64.

22. Beckerle P, Christ O, Windrich M, Schütz G, Rinderknecht S, Vogt J. User-centered prosthetic design: a methodological approach to transfer psychological factors to technical development. In: Proceedings of technically assisted rehabilitation 2013. European conference on technically assisted rehabilitation (TAR-2013), 14-15 March, Berlin, Germany; 2013.

23. Legro MW, Reiber GD, Smith DG, del Aguila M, Larsen J, Boone D. Prosthesis evaluation questionnaire for persons with lower limb amputations: assessing prosthesis-related quality of life. Arch Phys Med Rehabil. 1998;79(8):931-8.

24. Gallagher P, Franchignoni F, Giordano A, MacLachlan M. Trinity amputation and prosthesis experience scales: a psychometric assessment using classical test theory and rasch analysis. Am J Phys Med Rehabil. 2010;89(6):487-96.

25. Schürmann T, Beckerle P, Vogt J, Christ O. Sind Urteile von Experten unterschiedlicher Berufsbiografien einstimmig? Eine Studie zur professionellen Beurteilung von Beinprothesen. Orthopädie Und Technik. 2014;2(14):30-5.

26. Schürmann T, Beckerle P, Preller J, Vogt J, Christ O. Theoretical implementation of prior knowledge in the design of a multi-scale prosthesis satisfaction questionnaire. 2016.

27. Cavalcanti M, de Amorim Lima AM, Ferraz KM, Benedetti-Rodrigues MA. Use of virtual reality in gait recovery among post stroke patients: a systematic literature review. Disabil Rehabil Assist Technol. 2013;8:357-62.

28. Wade E, Winstein CJ. Virtual reality and robotics for stroke rehabilitation: where do we go from here? Top Stroke Rehabil. 2011;18:685-700.

29. Ferreira dos Santos L, Christ O, Mate K, Schmidt H, KrügerJ, Dohle C. Movement visualisation in virtual reality rehabilitation of the lower limb: a systematic review. 2016

Submit your next manuscript to BioMed Central and we will help you at every step:

- We accept pre-submission inquiries

- Our selector tool helps you to find the most relevant journal

- We provide round the clock customer support

- Convenient online submission

- Thorough peer review

- Inclusion in PubMed and all major indexing services

- Maximum visibility for your research

Submit your manuscript at www.biomedcentral.com/submit 